PRZEGLĄD NAUK HISTORYCZNYCH 2019, R. XVIII, NR 1

http://dx.doi.org/10.18778/1644-857X.18.01.10

\title{
Kilka komentarzy do wspomnień Józefa Zajączkowskiego (Notatki z czasów powstania w r. 1863 a mianowicie $w$ m. Eodzi $i$ jego okolicach)
}

\begin{abstract}
T est rzecza oczywista, że pamiętnik może być w miarę pewnym źródłem historycznym jedynie wówczas, gdy opisane $\mathrm{w}$ nim wydarzenia uzyskuja potwierdzenie $\mathrm{w}$ procesie triangulacji, tj. weryfikacji poprzez inne dostępne dokumenty (także osobiste), zawierajace te same informacje. W przeciwnym razie zbiór wspomnień nie powinien być traktowany jako materiał faktograficzny, ale literacki, skażony fikcja - przeinaczeniami, niedokładnościami, naznaczony subiektywizmem narratora. Przyczyną tych niedoskonałości jest zazwyczaj zawodność pamięci memuarysty, ograniczoność kompetencji albo kwestia ujęcia wynikająca $z$ przekonań i poglądów, temperamentu, gustów, ówczesnego punktu widzenia, postawy kulturowej ${ }^{1}$. Przekaz pamiętnikarski, choć zawiera-
\end{abstract}

* Wydział Filologiczny, Instytut Filologii Polskiej i Logopedii, Zakład Literatury Pozytywizmu i Młodej Polski, e-mail: ddsk@wp.pl.

${ }^{1} \mathrm{Z}$ ostatnich prac poświęconych temu zagadnieniu warto wymienić monografię zbiorową: Pamiętniki, dzienniki i relacje jako źródła do badań historycznych (XVIII-XX wiek), red. K. Karolczak, Kraków 2011; z dawniejszych: J. Bu kow s ki, Wartość poznawcza dokumentów pamiętnikarskich, „Pamiętnikarstwo Polskie” 1972, t. II, nr 4, s. 88-100; W. Czapliński, Pamiętniki jako źródło dla historyka nowożytnego, „Pamiętnikarstwo Polskie” 1972, t. II, nr 2, s. 3-7; S. Paul, O naukowym użytkowaniu dokumentów autobiograficznych, przekł. K. Radziwiłł, „Pamiętnikarstwo Polskie” 1976, nr 1/4, s. 97-113; A. Cieński, Interpretacja dzieła pamiętnikarskiego, [w:] Zagadnienia literaturoznawczej interpretacji, 
jący relacje nie zawsze wiarygodne, stanowi jednak przyczynek do mentalności autora, bywa również - zwłaszcza gdy dotyczy zdarzeń spektakularnych - świadectwem osobistych, a nierzadko i kolektywnych przeżyć. $Z$ natury wybiórczy opisuje memuar fragment minionego świata dostępny poznaniu autora: jego wiedzy lub domysłom. Często mieszają się one, tworząc palimpsesty fikcji i faktów. Czasem, gdy autor opatruje swoje relacje kwantyfikatorem wattpliwości lub narracja $z$ rzeczowej staje się afektywna, daje się je oddzielić; innym, pewniejszym sprawdzianem wiarygodności jest porównanie reminiscencyjnych odtworzeń $z$ odnalezionym materiałem archiwalnym.

Józef Zajączkowski w swym pamiętniku obejmującym chronologicznie powstanie $1863 \mathrm{r}$. opisuje ważniejsze wydarzenia $z$ okolic Łodzi, wspomina osoby $z$ nimi związane ${ }^{2}$. Jest obok memuaru Wiktora Jaworskiego ${ }^{3}$ i Józefa Malewskiego ${ }^{4}$ ważnym dokumentem dotyczącym regionu $z$ okresu powstańczego wrzenia. Reminiscencje Zajączkowskiego mają niemałą wartość poznawczą także dlatego, że autor - naczelnik powstania miasta Łodzi - był niejako w centrum wypadków, jako świadek i komentator. Wspomnienia spisywał on jednak - co sam zaznacza - po siedmiu latach, ten upływ czasu mógł więc spowodować zatarcie się w pamięci niektórych szczegółów. O samym autorze wiadomo stosunkowo mało, tzn. tyle, ile ujawnił on sam, oraz to, co zdołali ustalić zajmujacy się jego biografia badacze ${ }^{5}$. Niestety, dane te są niepełne lub wręcz nieprawdziwe, często są to jedynie zasłyszenia bądź repetycje.

red. J. Sławiński, J. Święch, Wrocław 1979, s. 287-296; Z. Wojtkowiak, O klasyfikacji interpretacji pamiętników. Uwagi i propozycje, „Studia Źródłoznawcze” 1980, t. XXV, s. 163-177; S. Herbst, Pamiętnik i relacja jako źródła do historii wojskowości, „Pamiętnikarstwo Polskie” 1972, t. II, z. 2, s. 8-10. O niesłabnacym zainteresowaniu tą problematyka świadczy jej podjęcie na sympozjum Historie ukryte $w$ pamiętnikach. Pamiętnik jako przedmiot i źródło badań naukowych, które odbyło się na Uniwersytecie Mikołaja Kopernika w Toruniu w maju 2018 r.

2 J. Zajączkowski, Notatki z czasów powstania w r. 1863 a mianowicie $w$ m. Łodzi i jego okolicach, [w:] Spiskowcy i partyzanci 1863 roku, red. S. Kieniewicz, Warszawa 1967, s. 111-159.

${ }^{3}$ S. Bellina [W. Jaworski], Notatki o powstaniu $w$ tęczyckim powiecie, [w:] Polska w walce, wybór A. Giller, Paryż 1868, s. 219-245.

4 Pamiętnik Jana Podkowy, weterana z 1863 roku, „Gazeta Łódzka” 1916, R. V, nr 230, s. 2 oraz nr 231, s. 2. Choć pamiętnik ten zawiera sporo informacji, zauważyć można zbyteczną egzaltację autora, mogąca generować skłonność do mityzacji.

${ }^{5}$ S. Płoski, Posłowie, [w:] J. Zajączkowski, op. cit., s. 160-167. Tu m.in. krótkie dzieje rękopisu wspomnień. Biografia Zajączkowskiego zajmowano się 
Podobnie rzecz się ma $z$ biografiami osób w pamiętniku Zajączkowskiego wskazanych jako animatorzy lokalnego zrywu powstańczego. Niektórzy $z$ nich mają obszerniejsze opracowania ${ }^{6}$, inni-drobne biogramy utrwalone w Polskim słowniku biograficznym, pozostali ulegli zapomnieniu.

Kwerenda archiwalna przyniosła kilka ustaleń dotyczących podstawowych informacji biograficznych, dzięki którym można uzupełnić dotychczasowa wiedzę o kilkorgu ludziach związanych $z$ powstaniem 1863 w Łódzkiem ${ }^{7}$, pozwoliła także na sprostowania i korekty.

\section{O autorze - Józefie Zajączkowskim}

Józef Antoni Jakub Ignacy Zajączkowski, syn Stanisława i Marcjanny z Lichnowskich, urodził się 24 lipca 1817 r. w krakowskiej dzielnicy Wesoła, ochrzczony został dwa dni później w kościele pw. św. Mikołaja ${ }^{8}$. Jego ojciec był nauczycielem w szkółce parafialnej przy tym kościele. Józef miał co najmniej jednego brata, Hipolita ${ }^{9}$

także w związku $z$ uprawianym przez niego zawodem fotografa. Niestety, w pracach tych na ogół powiela się te same informacje, nierzadko mylne.

${ }^{6}$ Bogata w szczegóły jest zrekonstruowana przez K. J a d c zy ka biografia księdza Czajkowskiego. Por. Ks. Józef Czajkowski-wikariusz parafii Wniebowzięcia NMP $w$ Łodzi i dowódca partii powstańczej $w 1863$ roku $w$ regionie łódzkim. Nieznane szczegóły z życiorysu, „Rocznik Łódzki” 2015, t. LXIII, s. 187-195. Podobnie rzecz się ma z biografią Józefa Dworzaczka, por. L. W a s zki ew i c z, Józef Dworzaczek - lekarz powstaniec, „Ziemia Łęczycka” 1959, nr 2, s. 1-2, niemała wartość ma również tekst J.A. Zi e m n i cki e g o, Zagadka Józefa Sawickiego: epizod z dziejów powstania styczniowego w Łęczyckiem, „Przegląd Historyczny” 1975, t. LXVI, z. 2, s. 273-281.

7 Spośród ważniejszych prac dotyczących tematyki powstania 1863 r. w regionie łódzkim warto wymienić te obszerniejsze: K. Jadczyk, J. Kita, M. Nartonowicz-Kot, Powstanie styczniowe $w$ Łodzi $i$ regionie. Studia $i$ Materiały, Łódź 2014; A. Bars zczews ka, Nurty walki. Udział Łodzi i okręgu łódzkiego w ruchach narodowowyzwoleńczych 1795-1864, Lódź 1971; oraz artykuły: L. W as zkiewicz, Poczatek powstania 1863 roku $w$ Łodzi. Wymarsz pierwszej partii, „Łódź w ilustracji”. Dodatek niedzielny do „Kuriera Łódzkiego” 1935, nr 3, s. 3-4; J. Wojtyński, Łódź wobec roku 1863, „Słowo Katolickie” 1937, nr 8, s. 132; H. Manikowski, Powstanie styczniowe 1863-1864 r. w powiecie łęcyyckim, „Studia i Materiały do Historii Wojskowości” 1962, t. VIII, cz. 2, s. 151-202; id e m, Walki wyzwoleńcze $w$ Łęczyckiem $w$ latach 1863-1864, „Ziemia Łęczycka” 1964, s. 117-140; L. Muszyńs ki, Początki działań powstańczych 1863 r. w Łodzi i okolicy, „Strzelec” 2005, nr 1, s. 5.

${ }_{8}$ Archiwum Narodowe w Krakowie [dalej: ANK], USC Kraków/parafia św. Mikołaja, akt nr $67 \mathrm{z}$ roku 1817.

${ }^{9}$ Hipolit Zajaczkowski był urzędnikiem Dyrekcji Policji w Krakowie. Zmarł 20 I 1885 r. w Krakowie. Był chrzestnym najstarszego syna Józefa. 
i co najmniej jedna siostrę, urodzoną w 1819 r. Teklę Teresę Annę ${ }^{10}$. Był artysta malarzem, potem zajał się fotografią. Bardzo ruchliwy, często zmieniał miejsca pobytu. Mieszkał przede wszystkim w Krakowie, ale również w Warszawie, podkrakowskich Proszowicach (tu miała siedzibę rodzinna gałaź Zajączkowskich), w Kazimierzu pod Łodzią, Zgierzu, w Łodzi, a potem znów w Krakowie, z przerwą na wyjazd do Paryża.

W wielu opracowaniach jest mowa o tym, że Zajączkowski mieszkał również w Rzeszowie, Krośnie i Jaśle. Wniosek ten jest wynikiem błędnego utożsamienia dwu osób zbiegiem okoliczności noszących to samo imię i nazwisko oraz wykonujących ten sam zawód. Należy w tym miejscu odwikłać owe qui pro quo. Józef Zajączkowski z Podkarpacia urodził się w roku 1838 prawdopodobnie w Rzeszowie, prowadził zrazu zakład fotograficzny przy ul. Sandomierskiej (dzisiejszej Grunwaldzkiej), następnie przeniósł się do Krosna, a przed rokiem 1891 do Jasła ${ }^{11}$, gdzie 28 grudnia 1906 r. zmarł ${ }^{12}$. Te ustalenia rozstrzygaja ostatecznie kwestie istnienia nie jednego, ale dwu Zajączkowskich i dezawuuja przypuszczenie, że byli ze sobą blisko spokrewnieni.

Powróćmy jednak do głównego wątku. Nie wiadomo, gdzie Zajączkowski uczył się malarstwa, można jednak przypuszczać, że w Krakowie. W latach czterdziestych, a może i wcześniej przebywał w Warszawie, wynajmował wówczas pokój na Lesznie; w marcu roku 1843 ożenił się z córką właścicieli domu, 17-letnią Józefa Aleksandra Chmielewską (ur. 1827), córką Walentego i Zofii ze Skibińskich ${ }^{13}$. Z tego czasu pochodzi znajdujący się w Muzeum Narodowym w Krakowie portret Zajączkowskiego namalowany przez warszawskiego artystę Adolfa Rochalewskiego. Rok później mieszkał już Zajączkowski z żoną w Krakowie (na Kleparzu pod numerem 12), gdzie w październiku w parafii św. Floriana odnowił swoje zaślubiny, deklarując stały pobyt na terenie Galicji ${ }^{14}$.

10 ANK, USC Kraków/parafia św. Mikołaja, akt nr 105 z roku 1819. W akcie tym jako matkę podano Marcjannę z Jecheszan. Można przyjąć, że była to pomyłka, $z$ aktem urodzenia Józefa zgadza się bowiem nie tylko imię matki, lecz także jej wiek.

${ }_{11}$ W Jaśle w 1891 r. zmarła żona Zajączkowskiego, Krystyna z Wychowańskich.

12 Archiwum Państwowe w Rzeszowie. Oddział w Sanoku, USC Jasło/parafia rzymskokatolicka, akt nr 192 z roku 1906.

${ }_{13}$ Archiwum Państwowe w Warszawie [dalej: APW], USC Warszawa/parafia św. Andrzeja, akt nr $50 \mathrm{z}$ roku 1843.

${ }^{14}$ ANK, USC Kraków/parafia św. Floriana, akt nr 34 z roku 1844. 
Zajączkowscy mieli co najmniej siedmioro dzieci urodzonych w latach 1844-1861. Najstarszy syn - Kasper przyszedł na swiat w Krakowie ${ }^{15}$, najmłodszy - Antoni w Zgierzu ${ }^{16}$. Na podstawie progenitury można ustalić miejsca pobytu rodziny. W Galicji pozostawali do roku 1854; w Krakowie urodziła się (oprócz Kaspra) Bronisława Olimpia ${ }^{17}$, następnie w Proszowicach - Julia ${ }^{18}$. Gdzie mieszkali Zajączkowscy w latach 1849-1853, nie udało się ustalić. W roku 1854 stale przebywali w Królestwie, najpierw w Warszawie, gdzie urodziła się Antonina Magdalena ${ }^{19}$. Być może w tym czasie Zajaczkowski pobierał nauki u „ojca polskiej fotografii”, Karola Beyera $^{20}$. W roku 1855 Zajączkowscy mieszkali w folwarku Kulig parafii Kazimierz pod Łodzią, w którym przyszli na świat trzej synowie: Kazimierz Hipolit ${ }^{21}$, Julian ${ }^{22}$ oraz Bronisław Wilhelm ${ }^{23}$. W Zgierzu zaś, w którym osiedli ok. roku 1860, urodził się, jak wspomniano, Antoni. W połowie roku 1862 Zajaczkowscy przenieśli się do Łodzi; tu przy Nowym Rynku 8 (dziś Plac Wolności) otworzyli zakład fotograficzny, który przenieśli następnie na ul. Konstantynowska 5 (obecnie Legionów). Silnie zaangażowany w konspirację otrzymał Zajaczkowski w październiku 1862 r. od Komitetu Centralnego Narodowego nominację na naczelnika miasta Łodzi ${ }^{24}$. Kilkakrotnie zagrożony dekonspiracja, w sierpniu zbiegł Zajączkowski do Krakowa, a już 2 października 1863 r. otworzył atelier fotograficzne przy ulicy Poselskiej w Hotelu Narodowym ${ }^{25}$. W roku 1865 wydał pracę albumowa Grobowce, pomniki i trumny królów polskich w Krakowie, w której zawarł 29 fotografii ${ }^{26}$.

Wiadomo jednak na pewno, że około 1870 r. wyjeżdżał Zajączkowski do Paryża, tam bowiem spisał swoje wspomnienia, które ukończył w znaczącym dniu - 3 maja. Umarł w Krakowie 3 paź-

\footnotetext{
15 Ibidem, akt nr 154 z roku 1844.

${ }_{16}$ Archiwum Państwowe w Łodzi [dalej: APŁ], USC Zgierz/parafia św. Katarzyny, akt nr $143 \mathrm{z}$ roku 1861.

17 ANK, USC Kraków/parafia św. Floriana, akt nr 185 z roku 1845.

18 ANK, USC Proszowice, akt nr $11 \mathrm{z}$ roku 1848.

19 APW, USC Warszawa/parafia św. Krzyża, akt nr 740 z roku 1854.

${ }^{20}$ Karol Beyer prowadził w Warszawie zakład fotograficzny w latach 1844-1867.

${ }^{21}$ APE, USC Kazimierz, akt nr $11 \mathrm{z}$ roku 1855.

22 Ibidem, akt nr $28 \mathrm{z}$ roku 1857.

${ }^{23}$ Ibidem, akt nr $18 \mathrm{z}$ roku 1859.

${ }^{24}$ Akt mianowania znajduje się w posiadaniu Muzeum Miasta Łodzi.

${ }^{25}$ I. Płażews ki, Dzieje polskiej fotografii, Warszawa 2003, s. 98.

${ }^{26}$ Druk odnotowany przez K. Estreichera, Bibliografia polska XIX stulecia, t. V, Kraków 1880, s. 227.
} 
dziernika 1905 r., skończywszy 88 lat, przeżył swoją żonę o prawie 13 lat (Józefa $z$ Chmielewskich umarła 30 grudnia 1892 r.) ${ }^{27}$. Oboje spoczywaja na Cmentarzu Rakowickim.

\section{Uzupełnienia do biografii Ignacego Radziejowskiego}

Zanim Zajaczkowski otrzymał mianowanie na naczelnika miasta Łodzi, funkcję tę od roku 1862 sprawował przybyły $z$ Warszawy i wydelegowany $z$ Komisji Skarbu Ignacy Radziejowski, kontroler w łódzkiej fabryce cygar Landau i Spółka. Zajączkowski miał do niego stosunek ambiwalentny. Choć pisał o nim: „człowiek młody, miękko wychowany, lekki, pragnący błyszczeć, bez doświadczenia i nadzwyczajnie bojaźliwy, niezdolny do życia twardego i energicznego, nie majacy wyobrażenia o potrzebach powstańczych", zaraz dodał: „pomimo tych wad okazał w końcu piękny charakter” nawiązujac do postawy Radziejowskiego podczas przesłuchania, gdy mimo tortur nie wydał nikogo, skazujac tym samym samego siebie na śmierć29. Zajączkowski zapisał również, że mimo nacisków, nie miał zamiaru karać swojego poprzednika, ograniczył się jedynie do nadzoru nad nim oraz udzieleniu mu rady, by zamiast brać udział w czynnej walce, poprzestał raczej na działalności administracyjnej.

Podstawowe źródło wiedzy o Radziejowskim, biogram sporządzony dla Polskiego słownika biograficznego przez Józefa Śmiałowskiego, w dużej mierze korzystającego ze wspomnień Zajączkowskiego, wymaga zasadniczych uzupełnień; autorowi hasła nieznane sa informacje o rodzinie Radziejowskiego, nie podaje także dokładnej daty jego urodzenia ${ }^{30}$. Warto zatem uzupełnić ten brak.

Ignacy Teodozjusz Radziejowski urodził się w Warszawie 1 lipca 1832 r. jako syn zecera (a nie nauczyciela, jak chce Śmiałowski ${ }^{31}$ ) Aleksandra Radziejowskiego, uczestnika powstania listopadowego, i Marianny z Czernielewskich ${ }^{32}$. Ojciec pochodził z Lublina, mat-

\footnotetext{
${ }^{27}$ Dane $z$ inskrypcji nagrobnej Zajaczkowskich.

28 J. Zajączkowski, op. cit., s. 112.

${ }^{29}$ Ibidem, s. 113.

30 J. Śmiałowski, Radziejowski Ignacy, [w:] Polski słownik biograficzny, t. XXX, Wrocław-Warszawa-Kraków 1987, s. 63.

${ }^{31}$ Autor hasła błędnie odczytał przypis Zajączkowskiego. Była w nim mowa - oprócz Radziejowskiego - także o Aleksandrze Skrudzińskim. Ojciec tego drugiego był właśnie nauczycielem. O nim niżej.

${ }^{32}$ USC Warszawa/parafia św. Andrzeja, akt nr 334 z roku 1832.
} 
ka spod Łęczycy ${ }^{33}$. Ignacy był trzecim z kolei dzieckiem Radziejowskich, miał dwie siostry - Mariannę Antoninę (ur. 1828) ${ }^{34}$ oraz Praksedę Marię (1830 $\left.35-1832^{36}\right)$. Prakseda zmarła tuż przed jego urodzeniem; niewykluczone, że i druga siostra umarła we wczesnym dzieciństwie ${ }^{37}$. Możliwe więc, że owe „miękkie wychowanie” Radziejowskiego wynikało $z$ sytuacji rodzinnej.

Według ustaleń Śmiałowskiego uczęszczał do szkoły wydziałowej w Radomiu. W Łodzi od połowy roku 1862 organizował konspiracyjną siatkę, współpracując $z$ reprezentującymi robotników i rzemieślników łódzkich dwoma setnikami: Leonem Tuszyńskim $\left(1817-1895^{38}\right)$ - tokarzem ${ }^{39}$ i Ludwikiem Kozubskim $\left(1816-1900^{40}\right)$ - tkaczem, gromadził broń i umundurowanie. Wskutek defraudacji i matactw swoich pomocników - jako odpowiedzialny za akcje - został posądzony o nadużycia i malwersacje, do których dołączyły także niewłaściwe decyzje i manifestowana pycha. Jeśli wierzyć Zajączkowskiemu, Radziejowski wraz z księdzem Józefem Czajkowskim agitował oficerów rosyjskich garnizonu łódzkiego, usiłując przeciagnać ich na stronę powstania. Niewiele jednak udało mu się w tym zakresie zdziałać ${ }^{41}$.

${ }^{33}$ Dane $z$ aktu zaślubin rodziców Ignacego, APW, USC Warszawa/parafia św. Jana, akt nr $19 \mathrm{z}$ roku 1826.

${ }^{34}$ APW, USC Warszawa/parafia św. Krzyża, akt nr 686 z roku 1828.

35 APW, USC Warszawa/parafia św. Andrzeja, akt 364 z roku 1830.

${ }^{36}$ Ibidem, akt $\mathrm{nr} 51 \mathrm{z}$ roku 1832.

37 Nigdzie nie trafiłam na ślad jej zamążpójścia ani zgonu. W skorowidzach z parafii św. Andrzeja z roku 1831 znajduje się natomiast nieidentyfikowana bliżej Marianna Radziejowska (akt nr 129); wskutek niedostępności akt nie można zweryfikować danych osobowych zmarłej.

38 Syn szewca - Jana Tuszyńskiego i Antoniny z Pietrzyckich, pochodził z Dabrowicy pod Kutnem. Trzykrotnie żonaty: $z$ Teodorą Winiecką (zm. 1849), z którą miał czworo dzieci zmarłych w niemowlęctwie, $z$ Marianną Budziak oraz Franciszka Grzegorzewska. W latach sześćdziesiątych, jeszcze przed powstaniem, był plantatorem tytoniu, stąd być może jego znajomość z Radziejowskim. Zmarł we wsi Krzywie: APŁ, USC Zgierz/parafia św. Katarzyny, akt nr 8 z roku 1895.

${ }_{39} \mathrm{~W}$ żadnej $z$ metryk: ani małżeństw, ani urodzeń potomstwa Tuszyńskiego nie znalazłam informacji, jakoby miał być tokarzem. Identyfikowany jest jako czeladnik szewski (1840), gospodarz rolny (1847), „plantyer tytoniu” (1862).

${ }^{40}$ Kozubski pochodził spod Łodzi, jego żona była Ernestyna Fiszer $z$ Łasku. Był - jak słusznie twierdzi Zajączkowski - ojcem kilkorga dzieci (w aktach parafii łódzkiej odnotowano pięć córek i dwu synów). Zmarł w 1900 r. w Łodzi: APŁ, USC Łódź/parafia Wniebowzięcia Najświętszej Marii Panny, akt nr 3451 z roku 1900.

${ }^{41}$ J. Zajączkowski, op. cit., s. 112-113. 
Zajączkowski ujawnia niewiele na temat udziału Radziejowskiego w walkach. $Z$ pewnością był on związany z Józefem Sawickim, a następnie $z$ Robertem Skowrońskim. Nie posłuchał rady następcy, tj. nie wycofał się do zatrudnień administracyjnych, stacjonarnych, podjął nawet, czując się pohańbionym własnym tchórzostwem, próbę samobójczą, odratowany kontynuował czynna walkę ${ }^{42}$. Został pochwycony w sierpniu 1863 r. wskutek - jak to wyjawił przed śmiercia - zdrady Aleksandra Skrudzińskiego ${ }^{43}$. Po półrocznym śledztwie został skazany na śmierć. Karę zatwierdził pułkownik Aleksander von Broemsen, naczelnik wojenny miasta Łodzi. Wyrok został wykonany. Radziejowskiego rozstrzelano 6 lutego 1864 r. w Grabinie pod Nowosolna ${ }^{44}$.

\section{Kiedy i gdzie urodzil się Józef Sawicki?}

Jedną $z$ najbardziej intrygujących i kontrowersyjnych postaci związanych $z$ ruchem powstańczym w Łódzkiem był Józef Sawicki, reprezentant czerwonych, radykał o niemałej charyzmie, który potrafił zjednywać sobie zwolenników. Zajączkowski pisze o nim bez entuzjazmu, ale bardziej obojętnie niż niechętnie ${ }^{45}$. Wiadomo o nim dużo więcej niż o autorze pamiętnika czy Radziejowskim dzięki wspomnianemu artykułowi Janusza Ziemnickiego opartemu na wiarygodnej dokumentacji ${ }^{46}$. Celem tego artykułu była nie tylko

42 Loc. cit.

${ }^{43}$ Aleksander Agapit Skrudziński (1838-1897) - syn nauczyciela szkoły elementarnej najpierw w Kałuszynie, a potem w Łodzi Józefa Skrudzińskiego i Zofii z Piotrowskich, urodzony w Kałuszynie (Archiwum Państwowe w Siedlcach, USC Kałuszyn, akt nr 86 z roku 1838). Siostra Skrudzińskiego - Józefa, która Zajączkowski nazywa „uczciwą i porządna kobietą, tuż przed powstaniem wyszła za mąż za kuzyna Radziejowskiego - Feliksa Czernielewskiego (APŁ, USC Łódź/ parafia Wniebowzięcia Najświętszej Marii Panny, akt nr 55 z roku 1862). Wynika stąd, że Skrudziński i Radziejowski byli spowinowaceni. Skrudziński był zamożnym fabrykantem (nie wiadomo, skąd miał pieniądze, jego rodzina nie należała do krezusów), po powstaniu założył w Łodzi farbiarnię. Zmarł w roku 1897 (ibidem, akt numer $158 \mathrm{z}$ roku 1897). Zajączkowski wspomina, że druga siostra Skrudzińskiego „udająca patriotkę, wyszła za Moskala”; ta informacja zyskuje potwierdzenie w metryce zaślubin Leontyny Skrudzińskiej ze Stanisławem Karnickim, urodzonym w Moskwie (ibidem, akt nr 55 z roku 1864). Karniccy zaraz po powstaniu mieszkali w Sieradzu, a następnie w Łowiczu.

${ }^{44}$ Aktu zgonu nie odnaleziono w żadnej z pobliskich parafii, nie ma jej również w Warszawie, gdzie mieszkali rodzice Radziejowskiego.

45 Por. A. Pło ski, op. cit., s. 164.

46 J.A. Ziemnicki, op. cit. 
rekonstrukcja jego biografii, lecz także posłużenie się nią w celu zobrazowania stosunków między frakcjami białych a czerwonych. Ta rzetelna i drobiazgowa praca wyjaśnia wiele nieścisłości i prostuje lapsusy Zajączkowskiego czy Belliny. O ile kwerendy Ziemnickiego przynoszą obfity plon badawczy dotyczacy działalności i śmierci Sawickiego, nie przyczyniły się do ustaleń na temat jego pochodzenia. Ziemnicki przywołuje jedynie to, co ujawnił Zajączkowski, tzn. że Sawicki przybył z Wielkiego Księstwa Poznańskiego.

Dzięki szerzej zakrojonym poszukiwaniom udało się dotrzeć do aktu urodzenia Sawickiego: przyszedł na świat w Kazimierzu Biskupim 14 listopada 1827 r. jako syn Stanisława Sawickiego, sukiennika, i Marianny z Borowskich ${ }^{47}$. Służył w wojsku pruskim, brał również udział w powstaniu wielkopolskim 1848 r. Przybył do podłódzkich Łagiewnik i - jako kleryk - był jakiś czas kwestarzem ${ }^{48}$.

\section{Historia Piotrowiczów}

Emocjonalne passusy $\mathrm{w}$ pamiętniku Zajączkowskiego wiążą się z małżeństwem Piotrowiczów ${ }^{49}$ - jak się zdaje - znanych bliżej autorowi. Czytamy tu więc o dzielnej obronie „bohaterki dnia [...], która nie chce się poddać. Ubija strzałem kozaka, rani drugiego i trzeciego konia, padajac pod ciosami carskich siepaczy, a nadbiegła piechota, pastwiąc się nad trupem walecznej Polki, zadaj[e] tyle ciosów bagnetami, że już i miejsca na nowe zabrakło"50. Zajaczkowski podaje w przypisie wiele nieprawdziwych informacji, $z$ których wynika, że znał jedynie te fakty, którym osobiście świadkował (przeinacza nawet panieńskie nazwisko Piotrowiczowej, myli miejsce zatrudnienia jej męża) ${ }^{51}$. Dość fantastycznym, utrzymanym w sentymentalnym duchu zaś jest fragment dotyczący śmierci Piotrowicza, który nie zginął w potyczce, ale zmarł tydzień później w miejskim szpitalu w Łodzi: „Pomiędzy tymi [tj. rannymi - D.S.-K.] był Piotrowicz, raniony kulą w nogę, gdy upadł zemdlony, przebity został wskroś piersi bagnetem, dopiero obdartym $z$ sukni i obuwia.

47 Archiwum Państwowe w Poznaniu. Oddział w Koninie, USC Kazimierz Biskupi, akt nr $93 \mathrm{z}$ roku 1827.

48 J. Zajacczkowski, op. cit., s. 121.

49 Obszerniej o tym: D. Samborska-Kukuć, Próba restytucji biografii. Maria Piotrowiczowa w świetle dokumentów, „Rocznik Łódzki” 2017, t. LXVII, s. 27-49.

50 J. Zajaczkowski, op. cit., s. 124.

${ }^{51}$ Loc. cit. 
Doktor zaręczał za jego wyzdrowienie przy podobnym pielęgnowaniu i przy wypełnianiu jego przepisów, jednakże wiedząc o jego poprzedniej słabości [tj. chorobie serca - D.S.-K.], zalecał oszczędzać szczególnie silnych wzruszeń. Przychodził zwolna do siebie, wiedząc tylko od otaczających go, że żona, raniona, jest obecnie u matki swojej, cieszył się więc dla siebie i dla niej, że przyjda do zdrowia. Tymczasem przysposobiono pogrzeb $\mathrm{w}$ mieście dla pięciu zmarłych rannych, a dla jego żony we wsi Radogoszcz pod miastem. 28 lutego wszystkie 6 trumien razem niesiono do kościoła na cmentarz i bito w dzwony, a to było słychać w sali cierpienia, gdzie weszła jedna $z$ tych pobożnych a gadatliwych kobiet. Zapytana przez Piotrowicza: "Komu to dzwonią?" $z$ pośpiechem odpowiedziała, pomimo dawanych znaków obecnych dozorujących kobiet: "Pańskiej żony to pogrzeb taki wspaniały". Było już po wszystkim, słaby dostał bicia serca i po chrześcijańsku kończył żywot męczeński na ręku żony naczelnika, powtarzając za nią modlitwę, która prosił, aby głośno mówiła"52.

Konstanty i Maria Piotrowiczowie to postaci dobrze znane łodzianom, ich nagrobek na Starym Cmentarzu przy ul. Ogrodowej, który zdobią dwie kosy, jest miejscem lokalnej pamięci o poległych w powstaniu 1863 r. Incydentalność udziału Piotrowiczowej w zrywie narodowym zrodziła wiele mitów. Generuja je także wspomnienia Zajączkowskiego. Wielowariantowość narracji o Piotrowiczowej, osadzona w paradygmacie legendy o Emilii Plater, odsłania mechanizm powstawania mitu o kobiecie-heroinie, potwierdzając teorie narratywistów o palipsestowości historiografii, demaskuje jednocześnie rodzima skłonność do fantazjowania wyrosłego na gruncie romantycznych wyobrażeń o ofiarności i męczeństwie. Spektakularność śmierci Piotrowiczowej spowodowała zawłaszczenie jej biografii w przestrzeni publicznej, stąd transformacje, których czynnikiem organizacyjnym były emocje i wyobraźnia narratora odpowiadającego na oczekiwania społeczne. Kwerendy archiwalne ujawniajace suche fakty (dokumentacja służbowa, metryki) oraz odczytywane w procesie triangulacji inne źródła przeczą większości mitemów, które zgodnie $z$ intencjami wytwórców i dystrybutorów miały stanowić nacechowany emocjonalnie, spójny i kompletny ekwiwalent życiorysu Piotrowiczowej

${ }^{52}$ Ibidem, s. 128. 
służący także celom ideologicznym ${ }^{53}$. Udało się zweryfikować wiek bohaterki, który dla potrzeb legendy znacznie zaniżono, wygląd, stan posiadania, rodzaj wychowania, zatrudnienia, a nawet progeniturę. Przekształcenia te, niektóre świadomie, inne mimowiednie, miały uformować jej biografię podług klisz i stereotypów właściwych narodowym kreacjom romantycznym w rodzaju „kamieni na szaniec".

Marianna Florentyna Piotrowiczowa $z$ Rogolińskich urodziła się 30 sierpnia 1834 r. w Kuźnicy Kiedrzyńskiej pod Kłobuckiem ${ }^{54}$; była córką Zygmunta, powstańca listopadowego, i Ansberty z Badyńskich $1^{\circ} \mathrm{v}$. Michalskiej. W roku powstania miała zatem blisko 30 lat, a nie 24, jak przyjęło się uważać. Wcześnie, bo już w 1839 r. straciła ojca $^{55}$. Po powtórnym zamążpójściu matki została, podobnie jak jej siostra Anna, oddana na wychowanie krewnym zmarłego Rogolińskiego. Maria wychowywała się u wujostwa Schulzów w Zalesiu pod Wieluniem, nie zaś - jak chca legendy - w „starym ojców dworze”, gdzie pod okiem „starego sługi” Kaspra Belki miała uczyć się fechtunku i strzelania. Nie było ani „starego dworu”, bo Radogoszcz stała się własnością matki Piotrowiczowej (a nie jej samej, jak głosza opowieści) dopiero w roku 1860 od dalekiego krewnego Badyńskich Stanisława Strzałkowskiego aktem darowizny z ustanowionym dożywociem, ani „starego sługi; tym ostatnim okazał się po weryfikacji w archiwach o rok od Marii starszy Karol Belkie, „strzelec z Radogoszczy"56. W Wieluniu Maria ukończyła czteroklasową pensję dla dziewcząt. Tam poznała swojego przyszłego męża ${ }^{57}$.

Konstanty Tomasz Piotrowicz przyszedł na świat 29 grudnia 1833 r. w Krzepicach w Częstochowskiem jako syn Andrzeja, dyrektora krzepickiej szkoły, i Ludwiki z Czapskich ${ }^{58}$. Był absolwentem Gimnazjum Piotrkowskiego, nauczycielem szkół elementarnych. Piotrowiczowie pobrali się 25 lutego 1854 r. ${ }^{59}$ Miejsca ich

${ }^{53}$ Dotyczy to zwłaszcza oralnych klechd rodzinnych. Por. T. Szew er a, Ostatni gest pani Marii, [w:] K. Fr ej dli c h, Uśmiech Ariadny. Antologia reportażu łódzkiego, Łódź 1973, s. 296-311.

54 Archiwum Archidiecezji w Częstochowie, USC Biała, akt nr 48 z roku 1834.

55 APŁ, USC Borszewice, akt nr 24 z roku 1839.

56 Wynika to $z$ aktu jego zgonu, Belkie poległ pod Dobrą. APŁ, USC Dobra, akt 29 z roku 1863. Spis poległych pod Dobra sporzadziła G. Mis salowa, Źródła do historii klasy robotniczej okręgu łódzkiego, Warszawa 1957, s. 538-546.

57 D. Samborska-Kukuć, op. cit., s. 35.

58 Archiwum Państwowe w Częstochowie, USC Krzepice, akt nr 1 z roku 1834.

${ }^{59}$ APŁ, USC Wieluń, akt nr 16 z roku 1854. 
pobytu wyznaczało zatrudnienie Piotrowicza: najpierw małżonkowie zamieszkali w Białej pod Wieluniem, następnie w samym Wieluniu, w końcu w podłódzkich Chocianowicach ${ }^{60}$. Mieli dwoje dzieci: Władysława $\left(1856^{61}-1893^{62}\right)$ i Stefanię (ok. 1860-?) ${ }^{63}$.

Piotrowiczowie byli mocno zaangażowani w działania na rzecz ludu i w pracę u podstaw. Jako patrioci uświadamiali narodowo ludność robotniczą, rzemieślniczą i wiejską; związani ze stronnictwem czerwonych i Józefem Sawickim agitowali do działań zbrojnych. Miejscem spotkań aktywu powstańczego okręgu łódzkiego stała się Radogoszcz. Tam lub w folwarku radogoskim należącym do siostry Piotrowiczowej, Anny Chojnowskiej zamieszkali Piotrowiczowie od wczesnego lata 1862 r.; zaangażowani w przygotowanie akcji powstańczej nie powrócili już jesienią do Chocianowic ${ }^{64}$. Gdy sformowany pod dowództwem Dworzaczka (po odsunięciu Sawickiego) oddział 300 osób (30 ułanów, 60 strzelców i 210 kosynierów) po przemarszu przez Brzeziny, Stryków, Zgierz oraz Łódź, gdzie w niedzielę poświęcono sztandar, przenocował z 22/23 lutego 1863 r. w Radogoszczy ${ }^{65}$, dołączyli do niego - jako ochotnicy - oboje Piotrowiczowie (Maria była w zaawansowanej ciąży, a jej akces mógł być spowodowany troską o chorego na serce męża, którego nie chciała opuszczać) wraz z grupa mieszczan zgierskich, oficjalistami oraz służbą. Dnia 24 lutego źle uzbrojony oddział został zaskoczony pod Dobra przez garnizon kozacki sztabskapitana Nawrockiego-Opoczyńskiego. Walka zakończyła się druzgocącą klęską Polaków. Gdy Piotrowiczowa zobaczyła, że jej mąż padł zemdlony ${ }^{66}$, mogła podejrzewać, że został zabity, a w akcie desperacji porwać się na nacierajacych kozaków. Wskutek ich ataku poległa na polu bitwy ${ }^{67}$. Jej okaleczone, poprzekłuwane bagnetami zwłoki sprowadzono do Łodzi i wydano je rodzinie za wysokim okupem. Kozacy zabili wówczas jej ojczyma - Marcina

${ }^{60}$ Akta tyczace szkoły elementarnej we wsi Chocianowice, APŁ, sygn. 101, k. 265-312.

${ }^{61}$ Ibidem, k. 265.

${ }^{62}$ APW, USC Warszawa/parafia św. Andrzeja, akt nr 445 z roku 1893.

${ }^{63}$ D. Samborska-Kukuć, op. cit., s. 37.

${ }^{64}$ Akta tyczace szkoły elementarnej..., k. 312.

65 A. Barszczewska, op. cit., s. 269.

66 „Wiadomości z Pola Bitwy” 1863, nr 5, s. 1.

67 APŁ, USC Łódź/parafia Wniebowzięcia Najświętszej Marii Panny, akt nr 52 z roku 1863. 
Michalskiego ${ }^{68}$. Konstanty Piotrowicz umarł w tydzień później, 3 marca 1863 r. w szpitalu miejskim ${ }^{69}$.

Ustalenia dotyczące życiorysu Józefa Zajączkowskiego, o którym dotychczas wiadomo było niewiele, oraz kilkorga osób wspomnianych w pamiętniku pozwalaja potwierdzić jedynie częściowo wiarygodność relacji memuarysty. Ograniczoność ta nie była na ogół spowodowana stronniczościa jego poglądów politycznych czy sympatiami społecznymi, ale połowicznością wiedzy, brakiem znajomości szczegółów, a niekiedy i kontekstów. Dzięki owocnym kwerendom archiwalnym można dokonać sprostowań i uzupełnień biogramów kilkorga łódzkich insurgentów przywoływanych w piśmiennictwie historycznym często sztafetowo, bez nowych rozpoznań. Niektóre $z$ uzgodnień uprawniają do częściowego przynajmniej objaśnienia ich sytuacji osobistej (Radziejowski) lub decyzji, jakie podejmowali (Piotrowiczowa), inne stanowia drobne przyczynki faktograficzne.

\section{Bibliografia}

\section{ŹRÓDEA RĘKOPIŚMIENNE}

Archiwum Archidiecezji w Częstochowie

USC Biała, akt nr 48 z roku 1834.

Archiwum Narodowe w Krakowie [ANK]

USC Kraków / parafia św. Mikołaja, akt nr 67 z roku 1817, akt nr 105 z roku 1819. USC Kraków / parafia św. Floriana, akt nr 34 z roku 1844, akt nr 154 $\mathrm{z}$ roku 1844, akt nr $185 \mathrm{z}$ roku 1845 .

USC Proszowice, akt nr $11 \mathrm{z}$ roku 1848.

Archiwum Państwowe w Częstochowie

USC Krzepice, akt nr 1 z roku 1834.

Archiwum Państwowe w Łodzi [APŁ]

Akta tyczace szkoły elementarnej we wsi Chocianowice, sygn. 101, k. 265-312. USC Borszewice, akt nr $24 \mathrm{z}$ roku 1839.

USC Dobra, akt 29 z roku 1863.

${ }^{68}$ Ibidem, akt nr 106 z roku 1863.

${ }^{69}$ Ibidem, akt nr $128 \mathrm{z}$ roku 1863. 
USC Kazimierz, akt nr 11 z roku 1855, akt nr 28 z roku 1857, akt nr 18 z roku 1859.

USC Łódź/parafia Wniebowzięcia Najświętszej Marii Panny, akt nr 3451 $\mathrm{z}$ roku 1900, akt $\mathrm{nr} 55 \mathrm{z}$ roku 1862, akt numer $158 \mathrm{z}$ roku 1897, akt nr 55 z roku 1864, akt nr 52 z roku 1863, akt nr 106 z roku 1863, akt nr 128 $z$ roku 1863.

USC Wieluń, akt nr 16 z roku 1854.

USC Zgierz, akt nr 143 z roku 1861, akt nr 8 z roku 1895.

Archiwum Państwowe w Poznaniu. Oddział w Koninie

USC Kazimierz Biskupi, akt nr 93 z roku 1827.

Archiwum Państwowe w Siedlcach

USC Kałuszyn, akt nr 86 z roku 1838.

Archiwum Państwowe w Warszawie [APW]

USC Warszawa/parafia św. Andrzeja, akt nr 50 z roku 1843, akt nr $334 \mathrm{z}$ roku 1832, akt 364 z roku 1830, akt nr 51 z roku 1832, akt nr 445 z roku 1893. USC Warszawa/parafia św. Krzyża, akt nr 740 z roku 1854, akt nr 686 z roku 1828.

USC Warszawa/parafia św. Jana, akt nr 19 z roku 1826.

\section{Prasa}

„Wiadomości z Pola Bitwy” 1863, nr 5.

\section{Opracowania}

Barszczewska A., Nurty walki. Udział Łodzi i okręgu łódzkiego w ruchach narodowowyzwoleńczych 1795-1864, Łódź 1971.

Bellina S. [W. Jaworski], Notatki o powstaniu $w$ łęczyckim powiecie, [w:] Polska $w$ walce, wybór A. Giller, Paryż 1868, s. 219-245.

Bukowski J., Wartość poznawcza dokumentów pamiętnikarskich, „Pamiętnikarstwo Polskie" 1972, t. II, nr 4, s. 88-100.

Cieński A., Interpretacja dzieła pamiętnikarskiego, [w:] Zagadnienia literaturoznawczej interpretacji, red. J. Sławiński, J. Święch, Wrocław 1979, s. 287-296.

Czapliński W., Pamiętniki jako źródło dla historyka nowożytnego, „Pamiętnikarstwo Polskie" 1972, t. II, nr 2, s. 3-7.

Estreicher K., Bibliografia polska XIX stulecia, t. V, Kraków 1880.

Herbst S., Pamiętnik i relacja jako źródła do historii wojskowości, „Pamiętnikarstwo Polskie" 1972, t. II, z. 2, s. 8-10.

Jadczyk K., Kita J., Nartonowicz-Kot M., Powstanie styczniowe w Łodzi i regionie. Studia i Materiały, Łódź 2014. 
Jadczyk K., Ks. Józef Czajkowski-wikariusz parafii Wniebowzięcia NMP w Łodzi $i$ dowódca partii powstańczej $w 1863$ roku $w$ regionie łódzkim. Nieznane szczegóły z życiorysu, „Rocznik Łódzki” 2015, t. LXIII, s. 187-195.

Manikowski H., Powstanie styczniowe 1863-1864 r. w powiecie łeczyckim, „Studia i Materiały do Historii Wojskowości" 1962, t. VIII, cz. 2, s. 151-202.

Manikowski H., Walki wyzwoleńcze w Łęczyckiem w latach 1863-1864, „Ziemia Łęczycka” 1964, s. 117-140.

Missalowa G., Źródła do historii klasy robotniczej okręgu łódzkiego, Warszawa 1957 , s. $538-546$.

Muszyński L., Początki działań powstańczych 1863 r. w Eodzi i okolicy, „Strzelec” 2005, nr 1, s. 5.

Pamiętnik Jana Podkowy, weterana z 1863 roku, „Gazeta Łódzka” 1916, R. V, nr 230, s. 2, nr 231, s. 2.

Pamiętniki, dzienniki i relacje jako źródła do badań historycznych (XVIII-XX wiek), red. K. Karolczak, Kraków 2011.

Paul S., O naukowym użytkowaniu dokumentów autobiograficznych, przekł. K. Radziwiłł, „Pamiętnikarstwo Polskie” 1976, nr 1/4, s. 97-113.

Płażewski I., Dzieje polskiej fotografii, Warszawa 2003.

Samborska-Kukuć D., Próba restytucji biografii. Maria Piotrowiczowa $w$ świetle dokumentów, „Rocznik Łódzki” 2017, t. LXVII, s. 27-49.

Szewera T., Ostatni gest pani Marii, [w:] K. Frejdlich, Uśmiech Ariadny. Antologia reportażu łódzkiego, Łódź 1973, s. 296-311.

Śmiałowski J., Radziejowski Ignacy, [w:] Polski słownik biograficzny, t. XXX, Wrocław-Warszawa-Kraków 1987, s. 63.

Waszkiewicz L., Józef Dworzaczek - lekarz powstaniec, „Ziemia Łęczycka” 1959, nr 2, s. 1-2.

Waszkiewicz L., Poczatek powstania 1863 roku $w$ Łodzi. Wymarsz pierwszej partii, „Łódź w ilustracji”. Dodatek niedzielny do „Kuriera Łódzkiego” 1935, nr 3, s. 3-4.

Wojtkowiak Z., O klasyfikacji interpretacji pamiętników. Uwagi i propozycje, „Studia Źródłoznawcze” 1980, t. XXV, s. 163-177.

Wojtyński J., Łódź wobec roku 1863, „Słowo Katolickie” 1937, nr 8, s. 132.

Zajączkowski J., Notatki z czasów powstania $w$ r. 1863 a mianowicie $w$ m. Łodzi i jego okolicach, [w:] Spiskowcy i partyzanci 1863 roku, red. S. Kieniewicz, Warszawa 1967, s. 111-167.

Ziemnicki J.A., Zagadka Józefa Sawickiego: epizod z dziejów powstania styczniowego w Eęczyckiem, „Przegląd Historyczny” 1975, t. LXVI, z. 2, s. 273-281. 